This item was submitted to Loughborough's Research Repository by the author.

Items in Figshare are protected by copyright, with all rights reserved, unless otherwise indicated.

\title{
The moral economy of digital gifts
}

\section{PLEASE CITE THE PUBLISHED VERSION}

http://journals.berghahnbooks.com/ijsq/

\section{PUBLISHER}

(c) Berghahn Journals in partnership with Zhejiang University and the International Association on Social Quality

\section{VERSION}

AM (Accepted Manuscript)

\section{PUBLISHER STATEMENT}

This work is made available according to the conditions of the Creative Commons Attribution-NonCommercialNoDerivatives 4.0 International (CC BY-NC-ND 4.0) licence. Full details of this licence are available at: https://creativecommons.org/licenses/by-nc-nd/4.0/

\section{LICENCE}

CC BY-NC-ND 4.0

\section{REPOSITORY RECORD}

Elder-Vass, Dave. 2019. “The Moral Economy of Digital Gifts”. figshare. https://hdl.handle.net/2134/18919. 


\title{
The Moral Economy of Digital Gifts
}

\author{
Dave Elder-Vass \\ Department of Social Sciences, \\ Loughborough University \\ Ashby Road \\ Loughborough \\ LE11 3TU \\ United Kingdom \\ d.elder-vass@lboro.ac.uk
}

Author bio: Dave Elder-Vass is a senior lecturer in sociology at Loughborough University, UK. His writing on social ontology and social theory includes two recent books: The Causal Power of Social Structures (2010) and The Reality of Social Construction (2012). Currently, he is working on alternative economic practices, particularly in the digital economy, and their implications for social theory and political economy. His book Profit and Gift in the Digital Economy is due to be published in 2016.

Note: This is a pre-publication version of a paper to be published in the International Journal of Social Quality. It may differ slightly from the published version. Please cite as: ElderVass, D. (2015) ‘The Moral Economy of Digital Gifts', International Journal of Social Quality 5(1), and refer to the published version for the final wording and pagination. 


\begin{abstract}
The significance of giving as a contemporary socio-economic practice has been obscured both by mainstream economics and by the influence of the anthropological tradition. Andrew Sayer's concept of moral economy offers a more fruitful framework for an economic sociology of contemporary giving, and one that appears to be largely consistent with social quality approaches. This paper analyses giving from the perspective of moral economy, questioning the view that giving is a form of exchange, and opening up the prospect of seeing it as the outcome of a more complex constellation of causal factors. It uses examples from the digital economy, in particular the phenomenon of open source software, which nicely illustrates both the progressive potential of digital gifts and the ways in which they can be absorbed into the commercial economy.
\end{abstract}

Keywords: digital economy, giving, open source software, reciprocity. 


\section{The Moral Economy of Digital Gifts}

The social practices that we call giving are a seriously neglected component of the contemporary economy. ${ }^{1}$ If, for example, we include the giving that goes on between parents/carers and the children for whom they care, the many favours we do for each other, charity, inheritance, present giving, and volunteering, then a substantial proportion of the economic transfers that occur in contemporary societies takes the form of giving. But for mainstream economics, giving is not part of the economy at all. Defining the economy purely in terms of that which is exchanged in markets and produced for the purpose of such exchange erases giving from the economy. If the economy is to be equated purely with the market economy, then giving is no part of the economy at all, or at best only a marginal part - the gift industry that sells us greetings cards and commodities to be used as presents. What kind of economy, then, is giving part of? And what kind of intellectual approach to the economy might enable us to make sense of it?

Andrew Sayer's conception of moral economy offers us potential answers to both of these questions. Recent uses of this term can be traced back to the work of EP Thompson, but the meanings attributed to it have been rather diverse (Hann 2010; Thompson 1971; Thompson 1991). Sayer's use of the term articulates two specific senses. On the one hand, the moral economy as an object of study is comprised of "all forms of provisioning, including those

${ }^{1}$ I would like to thank Gideon Calder, Andrew Sayer, and the other participants in the Seminar on Ethics and Social Theory: The Work of Andrew Sayer, Newport, Wales, 22 February 2013, for their stimulating discussion of an earlier version of this paper, and also Karen O’Reilly and Sandy Ross for their very useful comments on some of the arguments it employs. 
outside the cash economy” (Sayer 2004a: 2) rather than being confined to the market economy. Thus, for example, if a parent provides food for their child, or a volunteer goes shopping for an elderly person, these provisioning activities are just as economic as the purchase of the food or service as a commodity. If we fail to acknowledge this we not only obscure an element of the economy but also play into the hands of those thinkers who argue that the modern economy is inevitably and necessarily a market economy. The economy is also, for Sayer, a moral economy because it is not driven purely by the pursuit of individual self-interest (which is not to deny that self-interest is one factor) (Sayer 2004b: 80). Other factors, including for example emotions, caring, and normative influences also influence economic actions (Sayer 2003: 353).

Moral economy, however, is also the name for a kind of inquiry, which assumes both an analytical mode and a normative mode. In the former, it is "the study of the ways in which economic activities, in the broad sense, are influenced by moral-political norms and sentiments, and how, conversely, those norms are compromised by economic forces” (Sayer 2004b: 80). In this sense, it may be regarded as a variety of economic sociology, or perhaps as a refusal to subject the study of the economy to traditional disciplinary boundaries at all. In the latter, normative, mode it takes an evaluative stance towards "economic systems, actions and motives in terms of their effects on people’s lives” (Sayer 2004b: 80-1) while also being reflexive about "the standpoints from which these critiques are made” (Sayer 2004b: 81).

Moral economy is thus an ethical and political as well as a scientific approach, and as such would seem to complement the social quality approach; indeed it shares the social quality literature's focus on human flourishing and in particular its debts to Sen, Nussbaum and the capabilities approach (Sayer 2004a). While this paper is oriented to an application of the moral economy approach, it does so in the spirit of building bridges between similar traditions (cf Gasper 2011). Substantial overlaps also exist with notions of the "human 
economy”, “plural economy” and "solidarity economy” (Hart, Laville, and Cattani 2010), and with elements of the recent Convivialist Manifesto developed by a group of progressive European intellectuals (Käte Hamburger Kolleg 2014). All of these converge, at least, in taking an ethical stance to human flourishing, in seeing flourishing in much wider terms than the generation of financial assets and income, and in stressing the social determinants of flourishing.

This paper offers a moral economic analysis of a set of practices that belong firmly within the moral economy: the relatively recent but already widespread and important practice of offering digital gifts over the Internet. It begins, however, by considering giving more generally, and in particular the argument that giving is essentially a self-interested form of deferred exchange, a view that has, remarkably, permeated even critical contemporary perspectives on giving. By contrast, the paper will suggest, there are many different motivations for giving and in many cases no return is required.

The paper will then turn to digital giving. Free digital giving is ubiquitous on the Internet; web pages, blog entries, social media posts, and contributions to advice forums, for example, are mostly made freely available for use without any obligation to reciprocate. The paper will look a little more closely, however, at a particularly sophisticated form: the creation of free open source software, which has begun to 'compete' effectively with some of the most successful commodity software in the world. Open source illustrates the profoundly liberating potential of digital giving, but also demonstrates that not all digital giving is so progressive. As Barbrook puts it, "money-commodity and gift relations are not just in conflict with each other, but also co-exist in symbiosis” (Barbrook 2005 [1998]). 


\section{Giving and Reciprocity}

Existing sociological accounts of giving have been shaped by the work of the anthropologist Marcel Mauss, or rather by a single short book dating originally from the 1920s, the Essai sur le don, published in English as The Gift (Mauss 2002 [1950]). Mauss’s essay is itself in a sense a work of moral economy. He examined anthropological evidence relating to social practices in Melanesia and amongst native Americans, and historical evidence relating to pre-feudal Europeans, and on the basis of this argued that in pre-modern economies the market is marginal. Instead, these societies depended on cycles of deferred gift exchange, which worked in a very different way from the market but nevertheless performed some of the equivalent functions of economic circulation. For Mauss this was a way of criticising the market fundamentalisms of his day, in particular the idea that only markets can coordinate economies, and the utilitarian claim that all economic decisions are, or should be, made by rational calculation of self-interest (Douglas 2002: x, xviii; Mauss 2002 [1950]: 41, 96-8).

These gift economies, he argues, depend on cycles of giving which take the form of deferred exchanges. They are characterized by a strong set of social obligations to give, to accept gifts, and above all to reciprocate gifts: to return something else of equivalent value at a later date (Mauss 2002 [1950]: 3, 16-17, 50-55). To return an equivalent immediately was unacceptable in most social situations. This was tantamount to refusing the gift, by transforming the cycle of giving into an instantaneous exchange that conformed instead to the logic of barter (Bourdieu 1990: 105; Godbout and Caillé 1998: 10). To do so was to undermine the very point of the gift, in which the transfer of goods was secondary to a more fundamental purpose: the creation of a network of social obligations that served to stabilize social relations. The recipient of the gift accepted not only the material gift but also an obligation to reciprocate at some point in the future, an obligation that constituted a social tie 
between recipient and giver. The implication, as Mary Douglas makes clear in her foreword to the English translation of Mauss's book, is that there can be no free gifts, because in the gift economy every gift generates an obligation to reciprocate (Douglas 2002: ix-x). Mauss’s argument thus fits with the moral economy approach in a further respect: it sees economic transactions as being driven by systems of normative obligation as opposed to (or as well as) rational utilitarian calculations of interest.

However progressive Mauss's intentions, ${ }^{2}$ attempts to apply his model of the gift to contemporary societies have had unfortunate consequences. Mauss’s insistence on the centrality of reciprocity has been extended uncritically to contemporary giving, but his analysis of gift exchange does not necessarily apply to modern giving (Elder-Vass 2015b). As Testart has argued, the practices he analysed corresponded more closely to the modern practice of lending than that of giving (1998: 101-2). Seeing gifts as a form of deferred exchange potentially reinstates the utilitarian idea that calculation of self-interest is the motor of these transfers (Graeber 2011: 90), and unites theories of the gift with conventional economics of the market as varieties of exchangism (Elder-Vass 2015b; Pyyhtinen 2014: chapter 2). ${ }^{3}$

\footnotetext{
${ }^{2}$ Mauss was also actively committed to socialist politics and the cooperative movement; his work on giving must be seen in this light (Fournier 2006).

${ }^{3}$ According to Adloff, "Caillé traces the misconceptions that have arisen in regard to the interpretation of Mauss's theory of gift back to the fact that often no clear theoretical distinction was made between utilitarian interest-as-advantage and ludic interest-as-curiosity, which led to precipitate conclusions about the (egoistic) advantage-oriented stance of those taking part in gift-exchange” (Adloff 2014: 10).
} 
Bourdieu's work on giving is a prime example of this tendency (notably 1990: 97-106). Initially he proposes to analyse the practice of giving from two points of view, which he seems to suggest are equally significant (Adloff and Mau 2006: 103). On the one hand, there is the subjective point of view, the point of view of the actor, from which perspective giving is seen as an act of pure generosity, with no expectation of return and no calculation of reciprocity. On the other, there is the objective point of view, the view of the observing scholar: that careful comparison of giving relationships over a longer period of time reveals that reciprocity does occur, and to such a well-matched extent that it is inconceivable that the actors had not engaged in some degree of calculation. But far from giving these two views equal weight as understandings of the practice of giving, Bourdieu proceeds to label the actors' point of view as a misrecognition of the nature of giving. ${ }^{4}$ Both are equally important, he says, but not because he takes the actors’ point of view seriously as an account of giving. On the contrary, the actors' view is important because it provides an ideology of giving, a misrepresentation of it that allows it to function effectively in the building and maintenance of relationships despite the fact that in reality reciprocity rules (Bourdieu 1990: 105-6). The so-called subjective view, it turns out, is treated by Bourdieu as part of the object: as a phenomenon that contributes to the overall effect of the practices of giving and not at all as an account of giving that we should take seriously in its own right. Thus Bourdieu produces a thoroughly alienated and alienating account of giving: alienated because it reduces giving to a kind of rational calculating exchange, and alienating because it encourages us all, lay actors included, to treat it cynically as merely a hidden variety of the pursuit of self-interest. As Osteen puts it, "Bourdieu constantly criticizes economism, arguing that it fails to capture the

\footnotetext{
${ }^{4}$ In a later comment Bourdieu seems to accept that people are aware of the reciprocity he claims they misrecognize, but “act as if one did not know the rule” (Bourdieu 1997: 232).
} 
nuances of transactions as perceived by the actors... And yet his description falls victim to such economism by implying that the economic truth is the most basic one” (2002: 24). ${ }^{5}$

A second consequence of the Maussian perspective is that giving is sometimes seen as a kind of pre-modern alternative to the market; a mode of economic transfer and social integration that is replaced by the market in modern societies (Mauss 2002 [1950]: 59). With the rise of the market, it therefore seems that the gift becomes economically marginal (Adloff and Mau 2006: 99; Negru 2010: 198, 200; Zelizer 1994: 77) (though Mauss himself insisted on its continuing symbolic importance: see 2002 [1950]: 83). As Benkler has pointed out, “There is a curious congruence between the anthropologists of the gift and mainstream economics today. Both treat the gift literature as being about the periphery, about societies starkly different from modern capitalist ones” (2004: 332). A number of sociological treatments of giving have fallen into the trap of seeing contemporary giving as nothing more than the exchange of presents on ritual occasions such as birthdays and religious festivals: ${ }^{6}$

${ }^{5}$ Cheal questions Bourdieu's account of misrecognition on the grounds that actors are aware of reciprocity (Cheal 1988: 57) but seems to replicate his cynicism by dismissing the idea of generosity towards one's family as part of an "ideology of love" that helps to obscure their real motivations (Cheal 1988: 85-6). Godbout has a more persuasive response, seeing denials of the duty of reciprocity as moves that leave the recipient "as free as possible to reciprocate or not”, allowing any subsequent gift to act as something other than the deferred completion of an exchange (Godbout and Caillé 1998: 188).

${ }^{6}$ Notable examples are (Cheal 1988) and (Berking 1999). Intriguingly, Carrier criticizes Cheal on these grounds, and then confines his discussion of the modern gift to Christmas presents (Carrier 1995: 18, chapter 8). 
as, in effect, a residual survival from pre-modern society in a ritualized form of relatively marginal significance to our personal relationships.

This perspective, however, obscures the existence and significance of a vast range of other forms of giving that continue to be of vital importance in contemporary societies, not just in building and sustaining relationships, but also as a crucial element of economic provisioning (Godbout and Caillé 1998: 11; Negru 2010). The range of giving practices and their frequency varies in different cultural contexts, but may include, for example, gifts to formal charities, gifts to beggars, religious donations, volunteering, doing small favours for strangers, giving blood and organs, leaving bequests, buying drinks for friends, giving away unwanted goods (e.g. via services like Freecycle) and giving presents on ritual occasions such as birthdays. Perhaps the most significant of all, though, is giving within the family or household. Almost all of us depend utterly in our childhood on the provisioning of our needs by our parents or carers, and indeed such giving often continues on even into adulthood. For Godbout, for example, “the family is the primary site for the gift in society” (Godbout and Caillé 1998: 29). A substantial part of our contemporary economy, then, is not an exchange economy but a gift economy and thus part of what Kenneth Boulding called a grants economy: an economy of one-way transfers (Boulding 1973).

Furthermore, much of this giving is not reciprocal giving. Giving to one's children, for example, is not motivated primarily by the expectation that one will receive a material return of equivalent value from them at some point in the future (Cheal 1988: 8, 57-8; Godbout and Caillé 1998: 24). This is nicely illustrated by Daniel Miller's account of shopping, which he suggests is "primarily an act of love” (Miller 1998: 18) directed on the whole towards the benefit of other members of one’s household (Miller 1998: 12). Similarly, giving to charity is not motivated by the expectation that the recipient will make a return, and as we will see in 
the following sections, many digital gifts carry no sense of any obligation to reciprocate at all.

Even when there are elements of reciprocity in gift giving practices, exchangist readings of reciprocity may be utterly wrong. If, for example, I receive a birthday gift from you and a few months later I give one to you, the observer may see this as a case of one gift obligating a reciprocal return, a kind of deferred exchange. But this may be a complete misreading of the second gift: rather than being the completion of a deferred exchange of material equivalents, the second gift, and indeed the first one, may be understood, and understood rightly, by the participants as affirmations of commitment to their relationship with each other. The logic in such cases is not a logic of reciprocity of objects, in anything but the most superficial of senses, but a logic of mutual recognition and relatedness of people (Schrift 1997: 2). There is a kind of empiricism or even behaviourism involved in seeing a sequence in which one gift is followed by another that flows in the opposite direction and defining this as reciprocity. When such events are interpreted as deferred exchange, in opposition to the selfunderstandings of those involved, this privileges the analyst's exchangist theoretical preconceptions over the understandings of the actors. I do not suggest that such moves can never be justified, but they are always open to challenge.

We must also question the idea of equivalence in reciprocity: the very idea that we measure the value of a gift and thus whether it stands as an equivalent to some other gift imports the logic of the market into a context where it may be utterly alien. ${ }^{7}$ It is only from the perspective of the market, with its monetary measurement of exchange value, that such calculations can be made. Granted, pre-modern gift economies may have had normative standards of gift equivalence, and there may be remnants of such standards in specific

\footnotetext{
${ }^{7}$ I thank Andrew Sayer for this point.
} 
contexts today. But even when gifts are evaluated, their value need not be seen in terms of exchange value. Often what is more important to both giver and recipient is,

'bonding-value': this is what an object, a service, a particular act, is worth in the world of ties and in their reinforcement. This phenomenon is the polar opposite of accounting value and is completely glossed over by economic discourse, for which ties are synonymous only with exchange (Godbout and Caillé 1998: 173).

Bonding value is not just a product of what is spent on a gift, but a range of other factors. It is raised, for example, by a gift that shows that the giver "knows what the recipient likes" (Godbout and Caillé 1998: 174) and has chosen the gift to maximize the recipient's pleasure - demonstrating not only concern for their welfare and the devotion of one's time to it but also a degree of intimacy in the relationship. And it is raised by signs that the gift has been de-commercialized, through moves such as the removal of price tags, careful wrapping, and the addition of personalized labels, all indicating both concern for the recipient and a distancing of the object given from the anonymous form of the commodity (Berking 1999: 58; Carrier 1995: 29, 150; Godbout and Caillé 1998: 37; Zelizer 1994: 78). Even “bonding value”, however, is a concept in danger of being reinterpreted into the paradigm of exchangism, and we must resist any such slippage by reminding ourselves that "We cannot overlook generosity when we speak of the gift... just because a gift is reciprocated doesn't mean that it is only a mercantile exchange in disguise” (Godbout and Caillé 1998: 175).

Even apparently reciprocal gifts, then, may not fit the exchangist assumptions that are characteristic of the hegemonic discourses of neoclassical economics, and instead should be understood as parts of a moral economy: an economy of transfers that are products of emotional commitments, social relationships, and the normative environment rather than the pursuit of individual material profit, and that are productive of well-being rather than of 
Gross National Product. ${ }^{8}$ But many gifts are not reciprocal at all, and thus still further from any possibility of explanation within the exchangist framework.

\section{Free Gifts}

Perhaps the purest cases of the free gift, the gift given with no expectation of return, are gifts to strangers, as analysed by Richard Titmuss in his famous study of unpaid voluntary blood donation (Titmuss 1997). ${ }^{9}$ The volunteer blood donor expects nothing in return for this intensely personal donation; the donor does not know who will receive their gift, and the recipient has no knowledge of the identity of the donor. There may be rather vague hints of reciprocity at work in some cases - the donor who gives because they themselves benefitted from an earlier blood donation, for example - but this is not reciprocity in anything like the sense of giving a precise equivalent back to the original donor in completion of a deferred exchange. Indeed reciprocity is hardly the right word, even here: it might be more accurate to say that the original gift had sensitized the recipient to the social need for the free gift of donated blood and triggered a desire to contribute to meeting that need.

Blood donation, of course, is only one variety of the free gift, and a sub-type of a much larger group of free gifts - charitable giving, whether of money, goods, or in the case of volunteering, time. A great deal of charity is giving to strangers, and one function of organized charities is to act as an intermediary between donor and recipient and thus to remove any mutual knowledge and any sense of obligation for the recipient to reciprocate,

${ }^{8}$ Cheal also sees presents as transactions in a "moral economy”, which he defines as "a system of transactions which are defined as socially desirable (i.e. moral) because through them social ties are recognized, and balanced social relationships are maintained” (Cheal 1988: 15).

${ }^{9}$ For further discussion of free gifts, see (Elder-Vass 2015b). 
though not all charity is quite so pure: Zelizer, for example, documents some cases of nineteenth century philanthropy in which donors expected to exert influence on the lifestyles of recipients in exchange for their donations (Zelizer 1994: ch. 4).

On the side of donors, charitable giving is motivated by a range of factors. Sanghera, for example, reporting on a study interviewing charitable donors, volunteers and participants in charitable events, divides them into three groups, motivated primarily by (a) social interaction and enjoyment; (b) the opportunity to develop and display knowledge and skills; and (c) a desire "to express their sympathy, compassion and justice for distant and unknown others" (Sanghera 2012: 40). Clearly, many people do hope to get something back from free giving, but such hopes do not entail that the gift is a form of exchange, nor that it is purely selfinterested. Instead a more variable range of motivations are at work in charitable giving, some of them more oriented to the benefit of others and others less so.

The primary focus of this paper, however, is on digital giving, in the form of digital resources - binary files, encoded electronically and therefore easily transmitted across communication networks - that are placed in publically accessible locations on the internet with the intention that other users may take copies of them without payment. The vast majority of the world wide web is a digital gift, since most web pages are free digital resources (Barbrook 2005 [1998]; Berry 2008: 12). But besides simple web pages there are also other forms of digital gift on the Internet - files available for download from file-sharing services, videos on YouTube, and transfers of virtual resources within game worlds, for example (Ross 2011).

One of the most interesting groups of digital gifts is those that are created, not by individuals or conventional organizations, but by communities of creators who cooperate to create complex digital content that is then made freely available on the Internet. One high 
profile example is Wikipedia, which is also interesting as an example of entirely noncommercial collaborative production (Elder-Vass 2015b; O'Sullivan 2009; Reagle 2010; Shirky 2009: ch. 5; Zittrain 2008: ch. 6). This paper, however, will focus on a different and more ambivalent example: the case of open source software.

\section{Open Source Software}

Open source is the product of a counter-cultural movement amongst software programmers who have often been concerned by monopolistic and other restrictive practices of commercial software companies. Richard Stallman, a key figure in the development of the open source movement, argues that software should be free - “'free' as in 'free speech,' not as in 'free beer'” (Stallman 2010: 3), the point of this distinction being that it is not enough for software to be available at no cost: In addition users should be free to use it as they see fit, free to study how it works and modify it, and free to pass it on to others, with or without any modifications they have made. For this to be possible, users must have access not only to the executable code of the software - the form that is typically made available by commercial software companies - but also to the source code. The source code is the set of program instructions, written in a humanly-readable programming language, that is created by the programmers of the software. Source code needs to be processed further into machinereadable instructions before it can function as a program in a computer, but those machinereadable instructions are more or less impossible for humans to understand and modify. By distributing software only in the form of executable code, commercial software companies therefore prevent users from studying and modifying it. Open source software, by contrast, is supplied with both source and executable code, and often copyrighted under copyleft terms which allow free use, modification, and further distribution of the resulting software 
(Stallman 2010: 127-8). ${ }^{10}$ This might seem at first sight to be unnecessary - if a programmer intends anyone at all to use their work, why copyright or license it at all? The risk, however, is that commercial companies use their open code, modify it, and then seek to copyright the resulting product as proprietary commercial software - thus transforming the programmer's gift into a commodity that the company owns. By licensing their work under copyleft terms, programmers can ensure not only that their work is distributed freely but also that any commercial companies that modify it are legally obliged to make the modified versions available on the same terms (Stallman 2010: 127-8).

At first sight, the right to freely modify software might seem like nothing more than a charter for individualistic dabbling. It is unlikely that isolated programmers working on their pet projects would be able to produce software of the power and complexity that is routinely available from commercial software companies. But open source principles, combined with the modularity that is central to contemporary software design, make possible something much more powerful: collaboration among many programmers, each of whom works independently on tasks of their own choosing, and yet generating a loose collective capable of producing software that is as powerful and complex as the proprietary alternatives. Open source programmers identify problems and absences in the software, and modify the code in response. One programmer may fix a bug, another may redesign a function or write the code for a function that the software was previously lacking, and collectively they end up generating increasingly reliable and functional programmes. If multiple programmers all try to fix the same problem or add the same functionality and release the modified code back into the community, then whichever version seems to do the job best is most likely to be adopted

\footnotetext{
${ }^{10}$ The most widely-used form of copyleft is the GPL (the GNU General Public License), developed by Stallman.
} 
by other users - or perhaps another programmer will combine the best of several different versions. Many different programmers, then, who may never meet each other face to face, can cooperate to produce high quality software without the coordination of the market and with minimal hierarchy or authority being required. This is a model of moral economy that Benkler describes as “commons-based peer production” (Benkler 2002), but it is also a case in which ICT has enabled the development of new communities - new sites of social cohesion - and empowered their members both to produce wider social benefits and to realize their own capabilities for fulfilling creative work. To the extent that this is true, open source software communities contribute to producing social quality in some of the ways identified by Wallace (2012).

In practice, the open source model is not quite as decentralized as the description above might suggest, because most end users of software do not have the time or interest or indeed the technical capacity to choose which set of modifications to pull together to create their own version of a software product. For ordinary, non-technical users, open source software is only viable if it is made available in the form of releases - pre-selected sets of the best versions of the various modules currently available. To create a release, someone, or some group, must make decisions about what to include and exclude, link the various modules together in an easy-to-install package, and make this readily available to the public. Hence open source products require central co-ordinators who inevitably have authority over some aspects of the product concerned. Often these are programmers who have made fundamental contributions to the development of the product concerned - most famously, perhaps, Linus Torvalds, original author of the Linux kernel (Corbet, Kroah-Hartman, and McPherson 
2012). A particularly successful product like Linux may end up with several different individuals or organizations consolidating and distributing competing releases. ${ }^{11}$

The consequence has been to enable the creation of a range of extremely successful software. Because this software is free to acquire we cannot measure the scale of open source software usage in the monetary terms taken for granted by conventional economics, and because the labor that produces it is given freely, we cannot measure the cost incurred in creating it in those terms. It is possible to make some estimates of the latter, however: In 2008, the Linux Foundation estimated that it would cost $\$ 10.8$ billion to build the software in a typical distribution of the operating system Linux if it was developed commercially (McPherson, Proffitt, and Hale-Evans 2008). A recent video from the Linux Foundation also gives some clues as to the scale of its adoption: “over 850,000 Android phones running Linux are activated every single day”, Linux servers deliver 8 out of 10 financial transactions, “9 out of 10 of the world's supercomputers run Linux”, and “Google, Facebook, Twitter and Amazon are all powered by Linux” (i.e. use Linux as the operating system on their servers) (Linux Foundation 2012). Although Linux is the most successful open source product, there are many others. The open source product Apache is the most widely used web server software in the world (Netcraft 2013). Although Apache is largely invisible to ordinary web users who may be unaware that they are benefiting from it, a more visible product is the widely used web browser Firefox.

Open source software is given freely to its users, and developed in a decentralized collaborative fashion using labor that is freely donated to the project. In one sense it is a

${ }^{11}$ The term Linux refers to a complex collection of software that includes the Linux kernel, the heart of the operating system, but also many other open source products that are used alongside the kernel to produce a wide range of functionality for users. 
model for a moral economy, a post-capitalist form of economic production with overtones of Marx's vision of communism and Kropotkin's anarchistic view of societies based on mutual aid (Kropotkin 2006 [1902]), though as we shall see it is far from being free of commercial influence.

In a moment I will consider the motivations of independent individuals who contribute to such projects, but not all contributors to open source projects are independent individuals: in the case of the Linux kernel, for example (which may not be representative), the vast majority of development is done by programmers working for commercial software companies (Corbet, Kroah-Hartman, and McPherson 2012: 9). These software companies have a range of motivations (Elder-Vass 2015a). Some claim to be influenced by a sense of moral obligation to contribute to communities whose work they benefit from (Anderson-Gott, Ghinea, and Bygstad 2011: 113), but others have explicitly commercial reasons. In particular, companies who contribute to open source products develop skills and a reputation that enables them to sell a range of products and services to organizations that use the product (Anderson-Gott, Ghinea, and Bygstad 2011: 109; Red Hat 2012; Weber 2004: 195-203). Yet, although they are motivated by profit, these companies are not pursuing it in anything like the ways that are theorized in the economics of commodity production. They are making gifts to the open source community, without any guarantee of return, and hoping to benefit indirectly as a result. At such interfaces between the market economy and the moral economy strange hybrids grow.

The motives of individual open source programmers can also be somewhat instrumental (Lerner and Tirole 2002). Significant contributors receive recognition and prestige from others in the open source community, a kind of professional symbolic capital (Lerner and Tirole 2002: 213). In addition to being personally gratifying, such capital may also be convertible to a more economic form, since it enhances the programmer's CV and the 
possibilities of well-paid work (Lerner and Tirole 2002: 213, 217-220). It seems unlikely, however, that the distant prospect of such an outcome provides the initial motivation for many contributors, and there are many other motivations that fit much more readily with moral economy's understanding of economic action than with that of conventional economics. One is “the pleasure of creation” (Benkler 2002: 424) - many of these programmers enjoy the challenge of solving coding problems. For them, programming is not a burden that must be compensated for by some other reward, but a pleasure: the pleasure of labor in which the worker chooses her task, controls her own labor process and product, interacts with fellow workers as a free and equal individual, and exercises her creativity to create something of value to the wider human community. This is work as the obverse of alienated labor as described by Marx (1978 [1844]: 74-6), work freed from the tyranny of the market and instead harnessed to human flourishing.

\section{The Battle for the Digital Economy}

The Internet today is a battleground between two competing digital economies. On the one hand, we have the commercial economy lionized by neoliberal politicians and neoclassical economists which is generating new digital corporate monopolies (Morozov 2015); on the other we find, not the state, which is gradually being transformed into little more than a servant of this first economy, but rather the gift economy. The digital gift economy operates in many forms (for further examples see Benkler 2004: 381-397), but one of the most interesting is the collaborative form at work in phenomena like Wikipedia and the open source software movement, a form that is "sustainable and productive in the digitally networked environment without reliance either on markets or managerial hierarchy” (Benkler 2002: 374). This “underappreciated modality of economic production” (Benkler 2004: 276) has been marginalized in economic and indeed sociological discourse, and yet already constitutes a major sphere of economic activity. 
Such activities are enabled and stimulated by the technical characteristics of the digital environment (Barbrook 2005 [1998]) and the nature of information goods (Benkler 2002: 404). ${ }^{12}$ Digital giving is giving without sacrifice: digital goods are nonrival, meaning that we can give them without giving up the thing that we are giving away. At the same time, it costs virtually nothing to distribute these digital goods over the Internet. Combined, these factors have transformed the economics of information based goods, so that it is no longer essential for producers to achieve a return on every item they distribute. If a million people consume a digital product and only a tiny fraction of them contribute to its cost of production (whether by making a payment to the original producer or by donating labor themselves to further development of the product) this may be enough to sustain a vibrant information economy.

Despite this opportunity, and despite the many interesting giving practices that are blossoming on the Internet, there are also many strong reasons to restrain claims for the potential of the digital gift economy. One limitation arises from the very factors that have just been stressed: virtually costless distribution of gifts that entails no sacrifice by the donor is only a characteristic of digital information goods. There is little reason to believe that similar economic processes might roll back the non-digital market economy in the way that the open source movement has generated a tendency for the decommodification of software. ${ }^{13}$ Indeed, the digital gift economy itself clearly depends on other sectors of the economy that are currently dominated by the market: for example, the hardware and networks that make the

${ }^{12}$ Which does not mean, of course, that they are determined by the technology; how we respond to these technical opportunities also depends on social factors and individual agency. ${ }^{13}$ Benkler has expressed a similar caution (Benkler 2002: 381) but also identified some interesting cases of non-digital goods where giving seems to be efficient even in terms derived from conventional economics (Benkler 2004: 275-7). 
digital gift economy possible are themselves physical products created in the commercial economy, and independent programmers that contribute to open source software must have other sources of income to support them, which are often derived from the commercial economy (Barbrook 2005 [1998]).

Digital gifts can also be turned quite directly to the service of capital. There is an important range of giving practices that we may call commercial giving or inducement giving, in which a gift is given for the purpose of inducing a subsequent transaction that generates profit for the original donor (Anderson 2009; Elder-Vass 2015a: 245-248). Thus, for example, companies like Zynga give free access to computer games in which users are then presented with opportunities to purchase accelerated progress or enhancements to their in-game characters (Cheshire 2012). Similarly, web search services give us free search results in order to sell advertising on the same page (Battelle 2005: chapters 5-7; Elder-Vass forthcoming: chapter 8; Levy 2011: part 2). While some other forms of giving can be seen as alternatives to digital capitalism, inducement giving is very much a part of it: "an entanglement of gifts within the commodity form” (Fuchs 2008: 171).

Certain elements of the digital gift economy also face attempts at outright suppression by government, acting in the interests of pre-digital media corporations. Most notably, governments have been persuaded by lobbyists for these corporations to extend copyright protection in an attempt to prevent the free distribution of vast amounts of digital media products (Gillespie 2007: chapter 4; Lessig 2004). ${ }^{14}$ Open source software seems likely to escape this, partly because of some clever work on copyleft licensing, but perhaps more so, ironically, because of the many ways in which it has become embedded in commercial

${ }^{14}$ In marked contrast to the ways in which several of the major media industries were built on gaps in earlier copyright regimes (Lessig 2004: chapter 4). 
business. As we have seen, many IT businesses have found ways to make money out of open source software, and at least some major open source software products are predominantly developed at the expense of such companies. But this is only half of the picture: we must also recognize that commercial companies are amongst the largest beneficiaries of the financial savings that arise from using free open source software - these savings are a major reason for the massive 'market' shares of products like Linux and Apache.

Such entanglements warrant scepticism towards suggestions in the literature that phenomena like open source software herald the replacement of capitalism (Berry 2008: 98). Berry, for example, argues that these phenomena are "taking place within an intensification of capitalism rather than signalling its replacement” (2008: 101). While much of Berry’s argument is sound, he fails to recognize that new economic forms tend to develop in the interstices of older ones, and that such a position does not necessarily compromise their future potential. While the gift economy will never be a complete replacement for capitalism, it could arguably play a significant role in a post-capitalist future (Elder-Vass 2014; GibsonGraham 2006), and if so it will need to develop substantially within a system that is politically dominated by the interests of capital. Entanglements with commodity logic, in forms like copyleft licensing, and with commercial companies, as we see in the open source community, are an inevitable element of such development. Berry is right, however, to warn against over-optimism. There is always a risk of progressive moves being absorbed into new iterations of capitalism (Boltanski and Chiapello 2005).

\section{Conclusion}

Giving is a major form of economic transfer in contemporary societies and yet it is largely ignored by mainstream economics and indeed by Marxist political economy. Family care, charity, volunteering and the growing range of digital gifts are only some of the means by which giving is productive of human flourishing, and the scale of this contribution is such 
that it is misleading to think we live in a purely market economy (Benkler 2004: 331). Rather, we inhabit a moral economy that takes the form of a "gift-market nexus" (Negru 2010: 194).

The gift element of this economy is not only productive of flourishing through the goods it produces and transfers, but also through the opportunities it provides for building relationships, expressing our feelings, unalienated labor and the pleasure of giving: all things that contribute to the quality of social life but have no exchange value and thus are ignored by mainstream economics. It is one of the strengths of Andrew Sayer's approach to moral economy that, like the social quality approach, it allows us to see that these other sources of flourishing are at least as important as those things that are valued in monetary terms and should be given at least as much weight in decisions about how we run our societies.

Another is that it enables us to see that the pursuit of material gain through market exchange is far from the only form and far from the only motivator of economic activity, even in our contemporary, apparently capitalist-dominated economy. While some gifts are entangled with such motives, most are not a form of exchange or even an inducement to exchange. What is remarkable about digital giving is that while historically the market has been steadily spreading its tentacles deeper and deeper into the realm of the lifeworld, the rise of the Internet has contributed to some unprecedented processes of decommodification, such as we have seen with the growth of open source software.

At the same time, however, the digital sphere has seen the blossoming of a wide range of forms of giving that are deeply entangled with the capitalist economy. At least some giving practices have been open to subornment to the interests of commercial business; and others have been suppressed to protect those interests. Digital giving both competes with and threatens the market model and is developing within the commercial sector and being put to 
use by it. The digital economy is currently the front line in the struggle between moral and market economy.

\section{References}

Adloff, F. 2014. “Introduction: ‘Wrong life can be lived rightly’ Convivialism: Background to a Debate.” in Convivialist Manifesto: A declaration of interdependence. Duisburg: Käte Hamburger Kolleg / Centre for Global Cooperation Research.

Adloff, F. and S. Mau. 2006. “Giving, Social Ties, Reciprocity in Modern Society.” European journal of sociology 47(1): 93-123.

Anderson, C. 2009. Free: The future of a radical price. New York: Random House.

Anderson-Gott, M., G. Ghinea, and B. Bygstad. 2011. "Why do commercial companies contribute to open source software?” International journal of information management 32(2): 106-117.

Barbrook, R. 2005 [1998]. “The Hi-Tech Gift Economy.” in First Monday, vol. 2012.

Battelle, J. 2005. The Search. London: Nicholas Brealey.

Benkler, Y. 2002. “Coase's Penguin, or, Linux and The Nature of the Firm.” Yale Law Journal 112(3): 369-446.

Benkler, Y. 2004. “Sharing Nicely.” Yale Law Journal 114(2): 273-358.

Berking, H. 1999. Sociology of giving. London: Sage.

Berry, D. 2008. Copy, Rip, Burn. London: Pluto.

Boltanski, L. and E. Chiapello. 2005. The New Spirit of Capitalism. London: Verso.

Bourdieu, P. 1990. The logic of practice. Cambridge: Polity.

Bourdieu, P. 1997. "Marginalia - Some additional notes on the gift.” in The Logic of the Gift, ed. A. D. Schrift. New York: Routledge. 
Carrier, J. 1995. Gifts and Commodities. London: Routledge.

Cheal, D. J. 1988. The gift economy. London: Routledge.

Cheshire, T. 2012. “Test. Test. Test.” Wired UK, pp. 132-9.

Corbet, J., G. Kroah-Hartman, and A. McPherson. 2012. Linux Kernel Development: The Linux Foundation. http://go.linuxfoundation.org/who-writes-linux-2012 (accessed 29 June 2015).

Douglas, M. 2002. “Foreword: No Free Gifts.” pp. ix-xxiii in The Gift, M. Mauss. London: Routledge.

Elder-Vass, D. 2014. “Giving and Social Transformation.” Journal of Critical Realism 13(3): 261-285.

Elder-Vass, D. 2015a. “Commerce, community and digital gifts.” pp. 236-52 in Commerce and Community: Ecologies of social cooperation, ed. R. F. Garnett, P. Lewis, and L. Ealy. Abingdon: Routledge.

Elder-Vass, D. 2015b. “Free gifts and positional gifts: Beyond exchangism.” European journal of social theory OnlineFirst.

Elder-Vass, D. forthcoming. Profit and Gift in the Digital Economy. Cambridge: Cambridge UP.

Fournier, M. 2006. Marcel Mauss: A Biography. Trans. J. M. Todd. Princeton NJ: Princeton UP.

Fuchs, C. 2008. Internet and Society. New York: Routledge.

Gasper, D. 2011. “The Human and the Social: a Comparison of the Discourses of Human Development, Human Security and Social Quality.” International Journal of Social Quality 1(1): 91-108.

Gibson-Graham, J.K. 2006. The End of Capitalism (As we knew it). Minneapolis: University of Minnesota Press. 
Gillespie, T. 2007. Wired shut: copyright and the shape of digital culture. Cambridge, MA: MIT Press.

Godbout, J. and A. Caillé. 1998. The World of the Gift. Montreal: McGill-Queen's UP.

Graeber, D. 2011. Debt: the first 5,000 years. New York: Melville House.

Hann, C. 2010. “Moral Economy.” pp. 187-198 in The Human Economy, ed. K. Hart, J.-L. Laville, and A.D. Cattani. Cambridge: Polity.

Hart, K., J-L. Laville, and A.D. Cattani. 2010. The Human Economy. Cambridge: Polity.

Käte Hamburger Kolleg. 2014. Convivialist Manifesto: A declaration of interdependence.

Trans. M. Clarke. Duisburg: Käte Hamburger Kolleg / Centre for Global Cooperation

Research. http://www.gcr21.org/publications/global-dialogues/2198-0403-gd-3/

(accessed 29 June 2015).

Kropotkin, P. 2006 [1902]. Mutual Aid. Mineola, NY: Dover.

Lerner, J. and J. Tirole. 2002. “Some simple economics of open source.” Journal of Industrial Economics 50(2): 197-234.

Lessig, L. 2004. Free Culture. New York: Penguin.

Levy, S. 2011. In the Plex. New York: Simon \& Schuster.

Linux Foundation. 2012. "How Linux is built.”

https://www.youtube.com/watch?v=yVpbFMhOAwE (accessed 29 June 2015).

Marx, K. 1978 [1844]. “Economic and Philosophical Manuscripts of 1844.” pp. 66-125 in The Marx-Engels Reader, ed. R. C. Tucker. New York: WW Norton.

Mauss, M. 2002 [1950]. The Gift. Translated by W. D. Halls. London: Routledge.

McPherson, A., B. Proffitt, and R. Hale-Evans. 2008. "Estimating the Total Development Cost of a Linux Distribution.” The Linux Foundation.

http://www.linuxfoundation.org/sites/main/files/publications/estimatinglinux.html (accessed 29 June 2015). 
Miller, D. 1998. A Theory of Shopping. Ithaca, NY: Cornell UP.

Morozov, E. 2015. “Digital Technologies And The Future Of Data Capitalism.” Social Europe. http://www.socialeurope.eu/2015/06/digital-technologies-and-the-future-ofdata-capitalism/ (accessed 29 June 2015).

Negru, I. 2010. “The plural economy of gifts and markets.” pp. 194-204 in Economic Pluralism, ed. R. F. Garnett, E. K. Olsen, and M. Starr. Abingdon: Routledge.

Netcraft. 2013. "March 2013 Web server survey.” http://news.netcraft.com/archives/2013/03/01/march-2013-web-server-survey.html (accessed 29 June 2015).

Osteen, M. 2002. “Introduction.” pp. 1-41 in The question of the gift: essays across disciplines, ed. M Osteen. London: Routledge.

O'Sullivan, D. 2009. Wikipedia: a new community of practice? Farnham: Ashgate.

Pyyhtinen, O. 2014. The Gift and its Paradoxes. Farnham: Ashgate.

Reagle, J. 2010. Good Faith Collaboration. Cambridge, MA: MIT Press.

Red Hat. 2012. “The world's leading provider of open source enterprise IT products and services.” (accessed 12 March 2013).

Ross, S. 2011. "Everyday economics: ideas new and old from lay theories of economic life." PhD thesis, LSE, London.

Sanghera, B. 2012. “‘Am I bothered?’ Everyday morality and moral concerns and their implications for charitable giving and the Big Society.” pp. 37-44 in Philanthropy and a better society, ed. Centre for charitable giving and philanthropy. London: Alliance Publishing Trust.

Sayer, A. 2003. “(De)commodification, consumer culture, and moral economy.” Environment and Planning D: Society and Space 21: 341-357. 
Sayer, A. 2004a. “Moral Economy.” Lancaster: Department of Sociology, Lancaster University. http://www.lancaster.ac.uk/sociology/research/publications/papers/sayermoral-economy.pdf (accessed 29 June 2015).

Sayer, A. 2004b. “Moral Economy and Political Economy.” Lancaster: Department of Sociology, Lancaster University. http://www.lancaster.ac.uk/sociology/research/publications/papers/sayer-moraleconomy-political-economy.pdf (accessed 29 June 2015).

Schrift, A. D. 1997. “Introduction: Why Gift?” in The Logic of the Gift ed. A. Schrift. New York: Routledge.

Shirky, C. 2009. Here Comes Everybody. London: Penguin.

Stallman, R. 2010. Free Software, Free Society. Boston MA: GNU Press.

Testart, A. 1998. “Uncertainties of the 'obligation to reciprocate': A critique of Mauss.” pp. 97-110 in Marcel Mauss: A Centenary Tribute, ed W. James and N.J. Allen. New York: Berghahn Books.

Thompson, E.P. 1971. "The moral economy of the English crowd in the eighteenth century.” Past and Present 50: 76-36.

Thompson, E.P. 1991. Customs in Common. New York: New Press.

Titmuss, R. 1997. The Gift Relationship. New York: The New Press.

Wallace, C. 2012. “Can Information and Communications Technology Enhance Social Quality?” International Journal of Social Quality 2(2): 98-117.

Weber, S. 2004. The success of open source. Cambridge MA: Harvard UP.

Zelizer, V.A. 1994. The social meaning of money. New York: Basic Books.

Zittrain, J. 2008. The Future of the Internet. London: Penguin. 